\title{
New Australian Drosera taxa PUBLISHED SINCE ALLEN LOWRIE's MAGNUM OPUS
}

Thilo Alexander KrUeger $•$ Curtin University • Kent Street • Bentley • Perth • 6102 - Western

Australia・Australia・t.krueger@postgrad.curtin.edu.au

Allen Lowrie's Magnum Opus provided a major taxonomic revision of Australian Drosera L. (Droseraceae), describing 16 new species, four new natural hybrids, elevating ten former subspecies to species-level and resurrecting 12 species from synonymy (Lowrie 2014: 1268-1281). In addition, the true identities of several formerly widely misidentified species such as D. dichrosepala Turcz. and D. paleacea DC. were established. This revision is now widely accepted by flora checklists and taxonomic authorities at regional (e.g., the Western Australian Census; Percy-Bower \& Parker 2019, see also https://florabase.dpaw.wa.gov.au/), national (Australian Plant Census; https://biodiversity.org.au/ nsl/services/search/taxonomy), and international (e.g., World Checklist of Selected Plant Families; https://wcsp.science.kew.org) levels. Only one species described in the Magnum Opus, D. coalara Lowrie \& Conran of $D$. section Bryastrum Planch. (pygmy sundews), has since proven to represent a synonym and is now placed under D. citrina Lowrie \& Carlquist (Krueger \& Fleischmann 2020).

Taxonomy is an ever-changing field. New observations from the wild, herbaria and cultivation are constantly updating our understanding of many taxa and new species continue to be discovered at rapid pace. Since the publication of the Magnum Opus, six new Drosera taxa were formally described from Australia, comprising four new species and two new infraspecific taxa. Only one taxon, D. gunniana (Planch.) de Salas has been resurrected from synonymy and elevated to specieslevel (de Salas 2018). Of these seven newly described or resurrected taxa, three belong to Drosera section Ergaleium (DC.) Planch. ${ }^{1}$ (tuberous sundews) while the remaining four are placed in $D$. section Arachnopus Planch. (“D. indica L. complex"), D. section Bryastrum (pygmy sundews), D. section Lasiocephala Planch. (woolly sundews), and D. section Prolifera C.T.White ("Queensland sundews"). This raises the current number of recognized Drosera species in Australia to 161. Curiously, all seven taxa have been published by different authors (13 authors in total), highlighting a broad interest in Australian Drosera among taxonomists.

In the following, I provide a brief summary and discussion of all seven taxa described or resurrected since Allen Lowrie's Magnum Opus.

\section{Drosera albonotata A.S.Rob., A.T.Cross, Meisterl \& A.Fleischm. (2018) Fig. 1}

A new species of $D$. section Bryastrum (pygmy sundews) from south-west Western Australia. It closely resembles $D$. miniata Diels, producing a compact ground rosette and large orange-metallic flowers bearing dark centers and three thread-like styles. However, the flowers of $D$. albonotata bear white basal patches on their petals, a feature that appears to be unique to this species and allows rapid identification when flowering. The specific epithet albonotata (from the Latin for "white marked") is a reference to this distinctive flower color pattern. The species occurs in lateritic or clayey soils in Wandoo woodlands or low heath approximately 50 to $150 \mathrm{~km}$ due east of Perth, in a region generally referred to as the Western Australian Wheatbelt. Habitat loss due to agricultural clearing has been severe in this area and D. albonotata is thus currently listed as Priority 2 (a potentially threatened species requiring urgent surveying effort) under Western Australian legislation (Western Australian Herbarium 1998-).

${ }^{1}$ Four tuberous sundew sections mentioned in the Magnum Opus (Erythrorhiza, Luniferae, Macrantha, and Stolonifera) were sunk into section Ergaleium by Fleischmann et al. (2018) based on molecular data. 


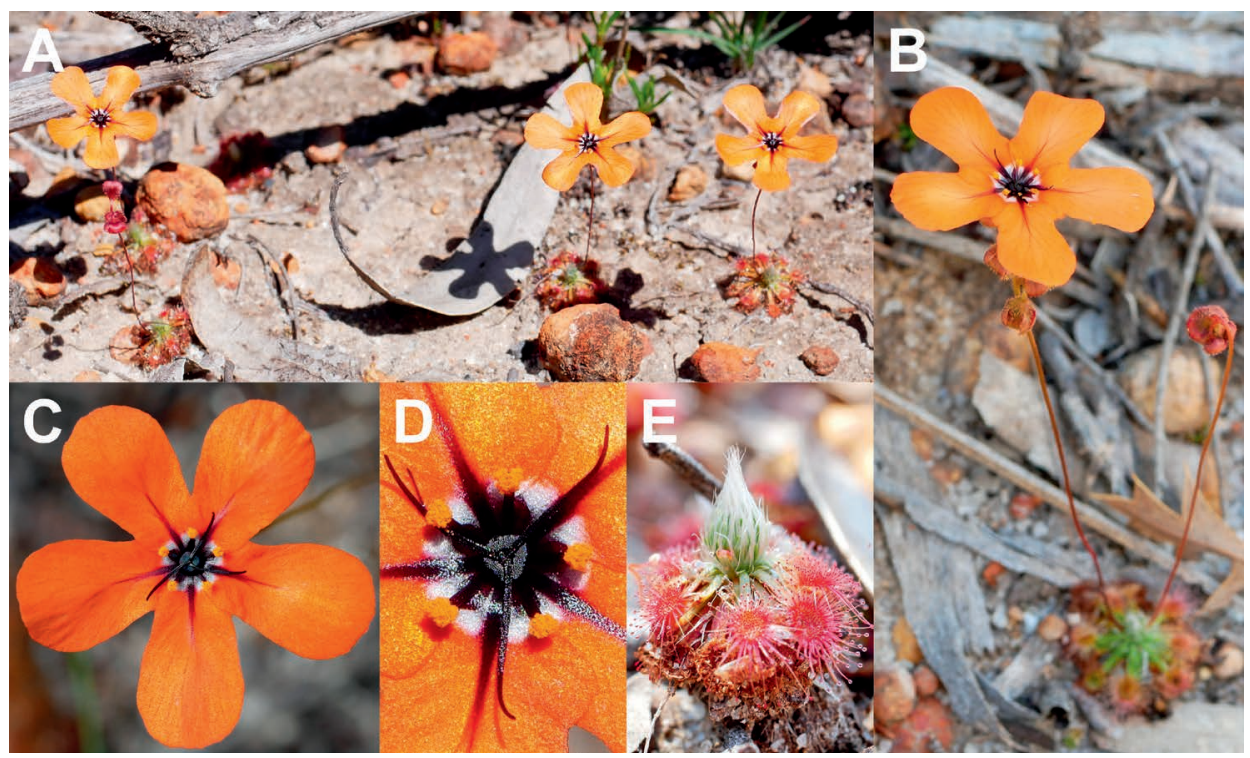

Figure 1: Drosera albonotata A.S.Rob., A.T.Cross, Meisterl \& A.Fleischm. A: A group of plants in full flower near York, Western Australia; B: Habit. The flower is about twice the diameter of the rosette in this species; C: Flower; D: Close-up of the flower center. The characteristic white spots on the petal bases are clearly visible; E: Rosette with stipule bud. Photos: Thilo Krueger.

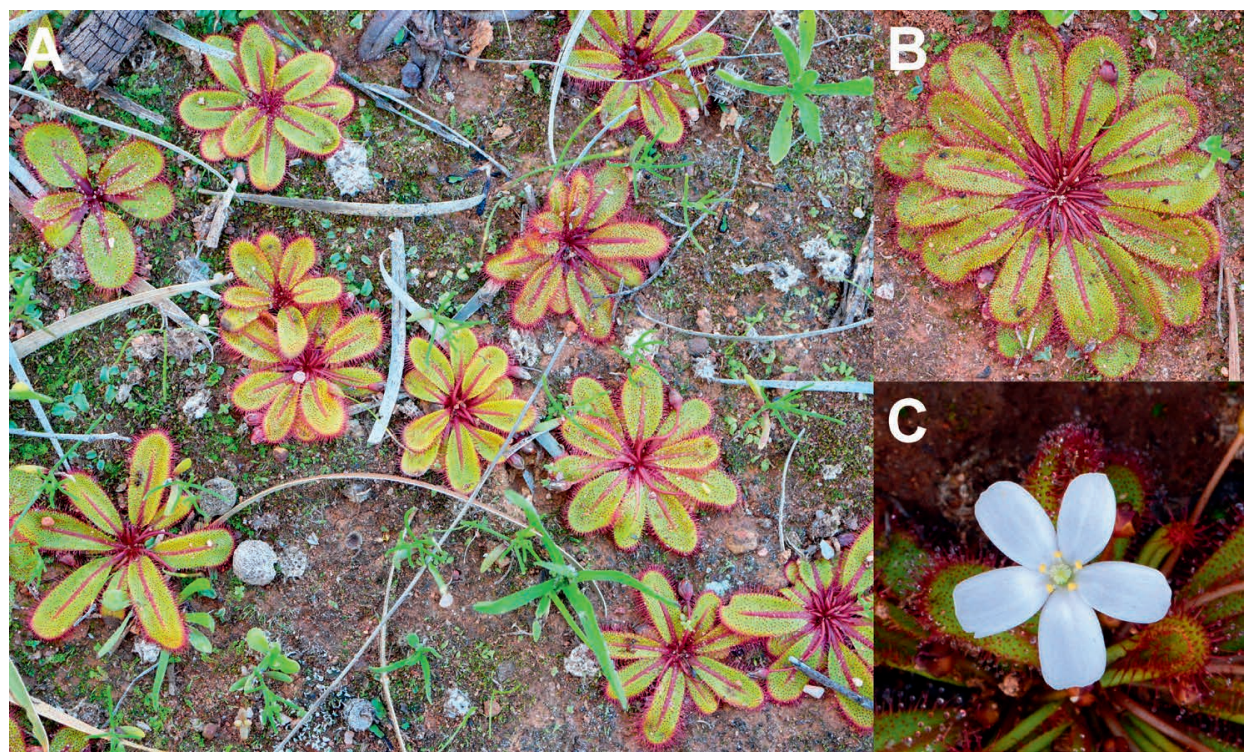

Figure 2: Drosera bulbosa subsp. coronata R.P.Gibson. A-B: Plants in full growth near Mingenew, Western Australia. The reddish leaf midribs contrast strongly with the overall olive-green leaves (Photos: Thilo Krueger); C: Close-up of the flower, note the yellow pollen color and crown-like style arrangement (Photo: Richard Nunn). 
Drosera bulbosa subsp. coronata R.P.Gibson (2013) Fig. 2

A new subspecies in $D$. section Ergaleium (tuberous sundews) from south-west Western Australia. This subspecies can be distinguished from D. bulbosa Hook. subsp. bulbosa and D. major (Diels) Lowrie by its striking olive-green leaf coloration with prominent red leaf midribs. Its flowers are also distinctive, featuring an annulus of short style segments around the top of the ovary and yellow pollen (D. bulbosa subsp. bulbosa and D. major have style segments evenly distributed on top of the ovary and white pollen). The subspecific epithet coronata refers to this characteristic crown-like style arrangement. This subspecies grows in loamy soils in Acacia woodlands at the bases of steep slopes and near river margins. It is only known from two locations near the small Wheatbelt towns of Mingenew and Mullewa, around 300 to $400 \mathrm{~km}$ north of Perth. Due to the few known locations, this taxon is currently listed as Priority 2 (a potentially threatened taxon requiring urgent surveying effort) under Western Australian legislation (Western Australian Herbarium 1998-).

\section{Drosera buubugujin M.T.Mathieson (2020) Fig. 3}

A new species of $D$. section Prolifera (Queensland sundews) from the south-eastern Cape York Peninsula in Queensland. While morphologically very similar to D. schizandra Diels, it can be most easily distinguished by its more narrow (usually oblanceolate) leaf shape, much longer inflorescences (which are up to $42 \mathrm{~cm}$ long vs. up to $15 \mathrm{~cm}$ long in D. schizandra) and white pollen (yelloworange pollen in D. schizandra). In addition, D. buubugujin features smaller flowers (only ca. 0.5 $\mathrm{cm}$ in diameter) and less bilobed anthers than D. schizandra. The specific epithet buubugujin refers to the Buubu Gujin Aboriginal Corporation lands upon which the only known herbarium specimens were collected by the authors in collaboration with the Traditional Owners of the area. This species grows on the sandstone escarpments north north-west of Cooktown, generally in sandy soils with moss along the banks of streams in forested areas. It is only known from two small populations in close proximity to each other which may be threatened by inappropriate fire regimes and invasive

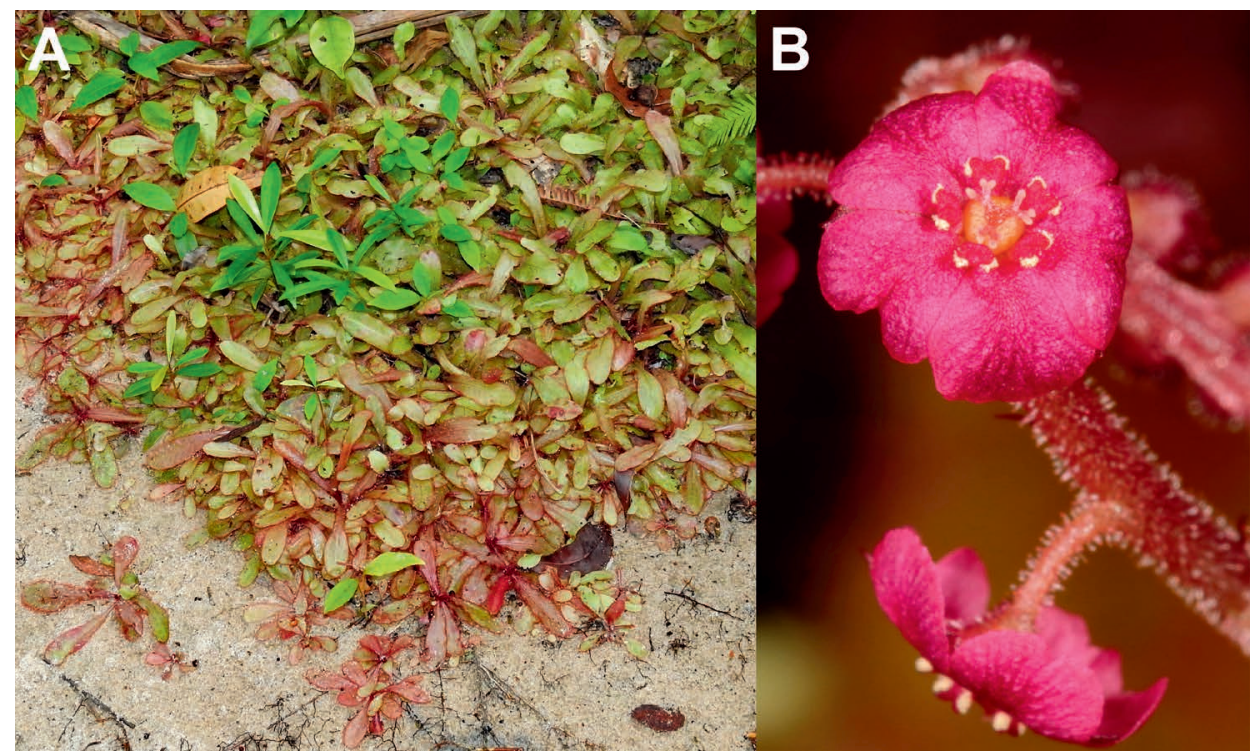

Figure 3: Drosera buubugujin M.T.Mathieson. A: A colony of plants growing on a stream bank in Muundhi National Park, Queensland; B: Close-up of the flower. Photos: Michael T. Mathieson. 


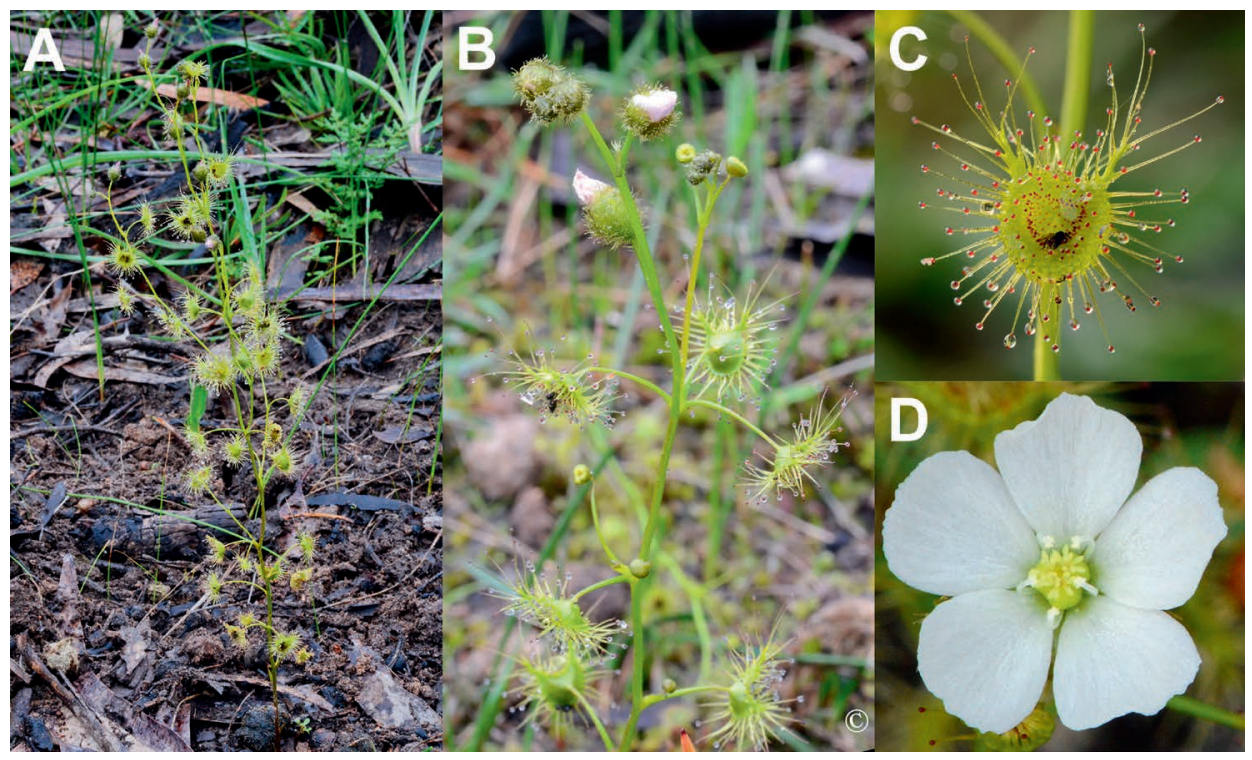

Figure 4: Drosera gunniana (Planch.) de Salas. A-B: Habit of flowering plants near Adelaide, South Australia. The relatively long stem that may only be branched near the top is characteristic for this species. Also note the hairy sepal indumentum; C: Close-up of the lamina; D: Close-up of a white flower. Photos: Richard Nunn.

grasses. Drosera buubugujin has thus been listed as Critically Endangered under Queensland's legislation (Queensland Department of Environment and Science 1995-2021).

Drosera gunniana (Planch.) de Salas (2018) Fig. 4

A newly resurrected and elevated taxon of D. section Ergaleium from south-east Australia and New Zealand. Previously often confused (or included) with D. hookeri R.P.Gibson, B.J.Conn \& Conran or D. peltata Thunb., this species can be distinguished by its $8-22 \mathrm{~cm}$ tall, usually solitary stem, yellow-green basal rosettes, inflorescences arising only from near the top of the stem, and its often pink flower color. By contrast, $D$. hookeri is a much shorter plant which usually branches from near its base and always has white flowers while D. peltata has very slender stems and reddish basal rosettes. This species is widely distributed in New South Wales, South Australia, Tasmania, and Victoria where it grows in a range of grassy habitats at low to mid elevations. In addition, plants from the Northland Peninsula in New Zealand (which were previously known as D. peltata or D. hookeri) have recently been confirmed to represent D. gunniana (de Lange 2021). This species appears to be relatively common across a large geographic area and is thus unlikely to be currently threatened.

Drosera huegelii var. phillmanniana Y.-A.Utz \& R.P.Gibson (2017) Fig. 5

A new subspecies in D. section Ergaleium from Stirling Range National Park in south-west Western Australia. This variety differs from $D$. huegelii Endl. var. huegelii mainly by its much smaller size, reaching a maximum of only $12 \mathrm{~cm}$ ( $v s$. up to $50 \mathrm{~cm}$ in $D$. huegelii var. huegelii) and only producing 1-3 flowers per plant (vs. 3-20 flowers per plant in D. huegelii var. huegelii). The epithet phillmanniana honors Phillip (Phill) Mann (1951-2014), a Western Australian carnivorous plant enthusiast and taxonomist who recognized the distinctiveness of this taxon and brought it to the attention of the authors. 


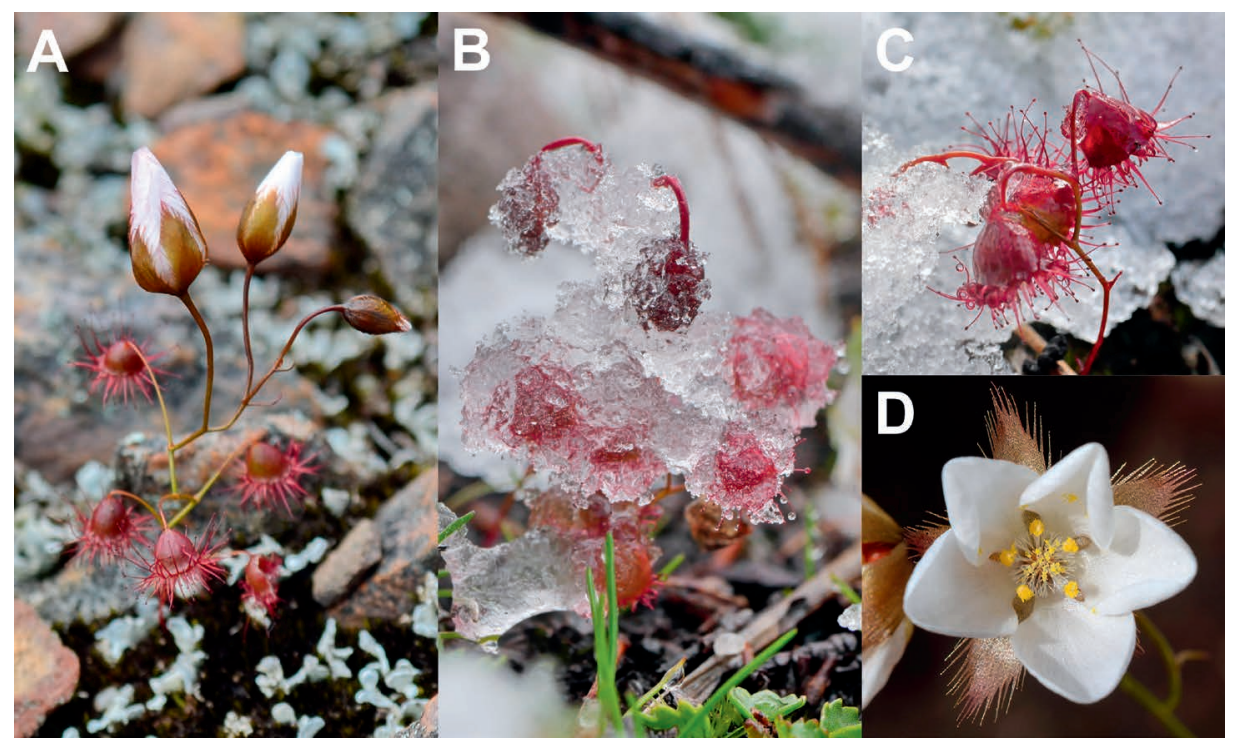

Figure 5: Drosera huegelii var. phillmanniana Y.-A.Utz \& R.P.Gibson. A: Habit of a flowering plant in Stirling Range National Park, Western Australia (Photo: Thilo Krueger); B: Flowering plant enclosed in ice and snow following a strong cold front on 17 August 2019 (Photo: Thilo Krueger); C: Close-up of the strongly bell-shaped leaves of this taxon (Photo: Thilo Krueger); D: Flower (Photo: Yves-Andre Utz).

Drosera huegelii var. phillmanniana is only known from the highest mountains of the Stirling Range, occurring above ca. $800 \mathrm{~m}$ elevation in open, wind-exposed montane heath. This habitat, which the taxon shares with D. monticola (Lowrie \& N.G.Marchant) Lowrie, is known for being the only place in Western Australia that regularly experiences light frost and snow during winter and spring. As this is also the growing and flowering time of $D$. huegelii var. phillmanniana, it is possible to find plants enclosed in ice and snow during this time (Fig. 5). Only known from very few populations across a limited range, this taxon has been listed as Priority 2 (a potentially threatened taxon requiring urgent surveying effort) under Western Australian legislation (Western Australian Herbarium 1998-).

\section{Drosera margaritacea T.Krueger \& A.Fleischm. (2021) Fig. 6}

A new species of $D$. section Arachnopus (" $D$. indica complex") from the Kimberley region of northern Western Australia. Previously often confused with D. finlaysoniana Wall. ex Arn., this species can be readily distinguished by its enormous, up to $65 \mathrm{~cm}$ tall inflorescence often bearing 50 or more relatively large flowers (which are up to $3 \mathrm{~cm}$ in diameter). Its shortly petiolate leaves bear 20-50 translucent-white stalked secretive glands near their bases that produce potentially resinous mucilage drops which do not desiccate even in dried herbarium specimens. The specific epithet margaritacea (from the Latin for "pearl-bearing") refers to this distinctive type of gland, as well as to the swollen, yellow-colored anther connective extensions. Drosera margaritacea occurs in beige to red sandy soils (Pindan) amongst dense grassy vegetation near seasonally wet swamps, creeks, and seepages. Its distribution covers a large part of the western Kimberley region, ranging from the base of the Dampier Peninsula in the west to near Fitzroy Crossing in the east and northwards to the Yampi Peninsula. Given this relatively wide distribution and large population sizes reported from several locations, this species is not currently considered to be threatened. 


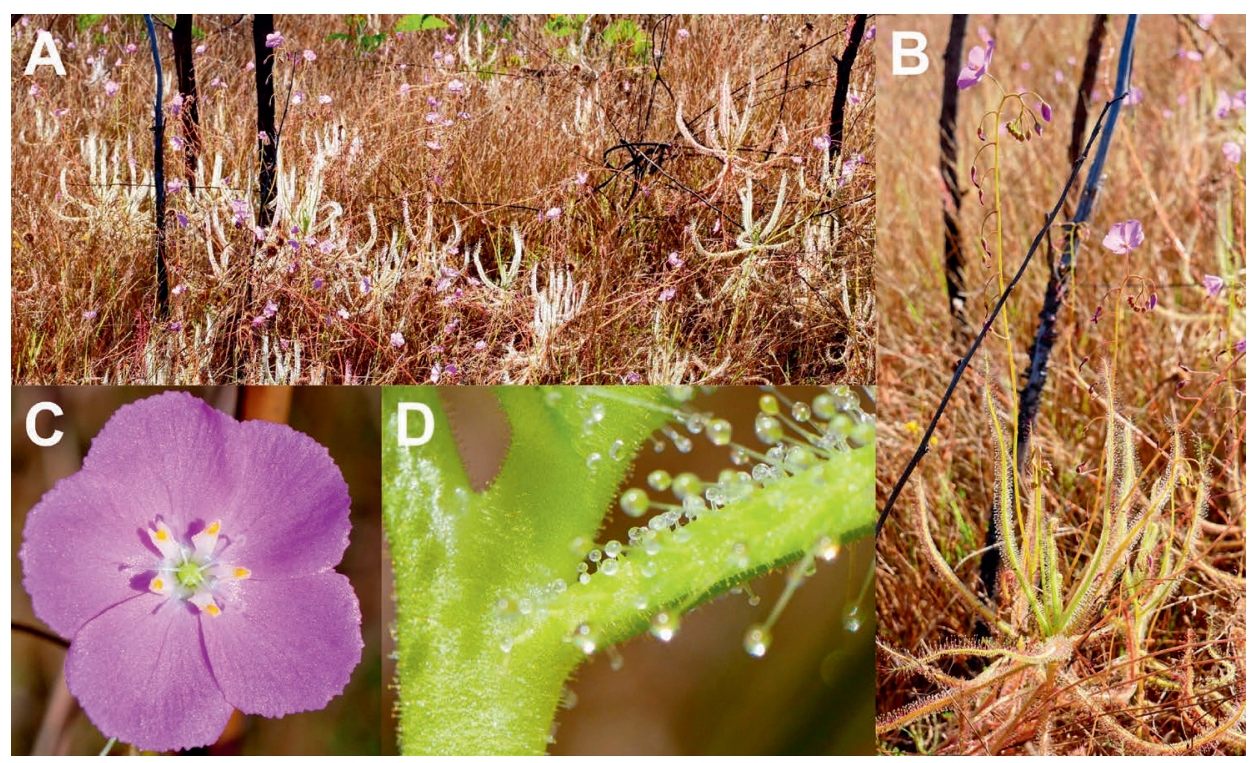

Figure 6: Drosera margaritacea T.Krueger \& A.Fleischm. A: A large population of this species growing near Derby, Western Australia; B: Habit. Note the upright, exceptionally long, and many-flowered inflorescences; C: Flower with the swollen, yellow-colored anther connective extensions clearly visible; D: Close-up of the distinctive translucent-white stalked secretive glands which cover the adaxial petiole surface. Photos: Thilo Krueger.

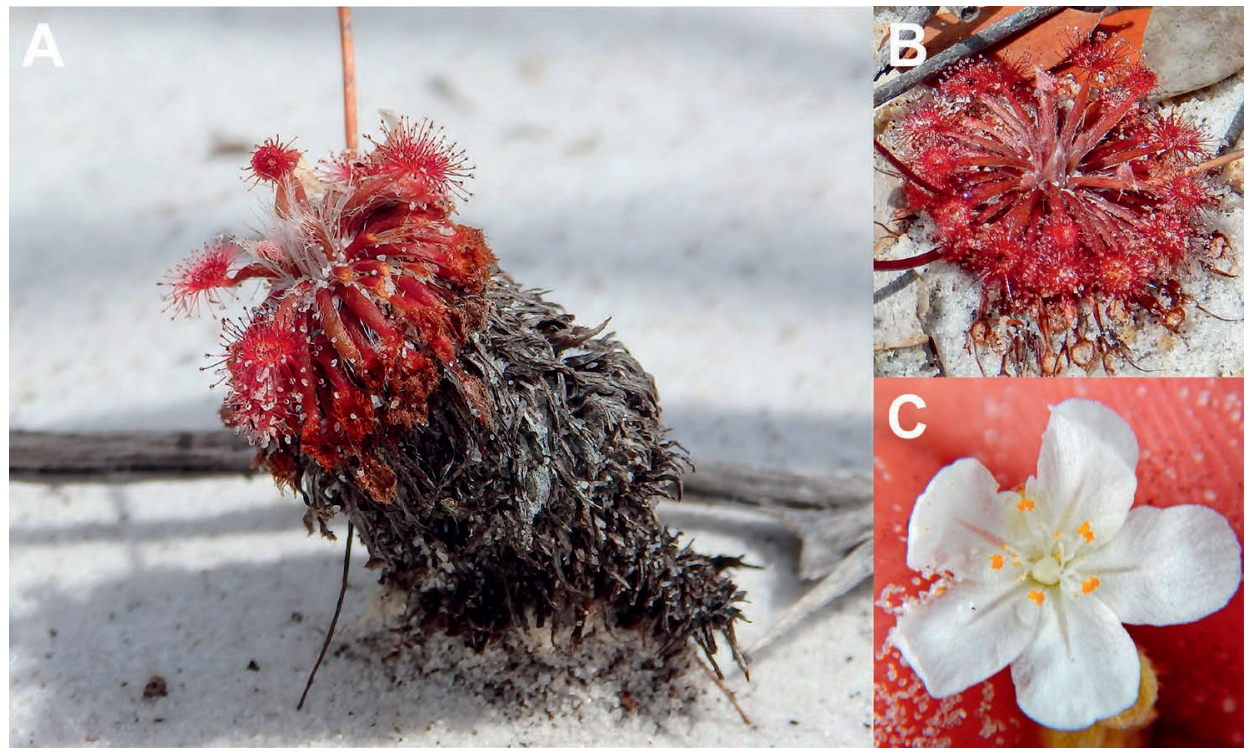

Figure 7: Drosera stipularis Baleeiro, R.W.Jobson \& R.L.Barrett. A: Habit of a plant growing in its typical sandy habitat near Cooktown, Queensland; B: Rosette; C: Close-up of the flower. Photos: Paulo C. Baleeiro. 
Drosera stipularis Baleeiro, R.W.Jobson \& R.L.Barrett (2020) Fig. 7

A new species of $D$. section Lasiocephala (woolly sundews or " $D$. petiolaris R.Br. ex DC. complex") from the Cape York Peninsula in Queensland. This species is morphologically very similar to D. petiolaris but can be differentiated by its almost pygmy-sundew-like appearance, producing slender stems covered with previous season's growth and unusually prominent stipules (hence the specific epithet stipularis). However, its inflorescence closely resembles $D$. petiolaris, although it lacks any hairy indumentum below the buds and bears shorter pedicels. Drosera stipularis grows in moist white sand within low heath and sedges. While only known from two localities north of Cooktown, it is not currently considered to be threatened (Queensland Department of Environment and Science 1995-2021).

Acknowledgments: Richard Nunn, Michael T. Mathieson, Paulo C. Baleeiro and Yves-Andre Utz are thanked for providing photographs of the recently described Drosera taxa. I would also like to thank Andreas Fleischmann, Allen Lowrie, Richard Nunn, Greg Bourke, Manfred Meisterl, and Alastair Robinson for fruitful discussions on Australian Drosera taxonomy over the past decade.

\section{References}

Baleeiro, P.C., Jobson, R.W., and Barrett, R.L. 2020. Drosera stipularis, a new species for the D. petiolaris complex from Cape York Peninsula, Queensland. Telopea 23: 35-40.

Gibson, R.P. 2013. Drosera bulbosa subsp. coronata (Droseraceae) from the Northern Goldfields of Western Australia. Telopea 15: 99-105.

de Lange, P.J. 2021. Drosera gunniana Fact Sheet (content continuously updated). New Zealand Plant Conservation Network. https://www.nzpen.org.nz/flora/species/drosera-gunniana/

de Salas, M.F. 2018. Drosera gunniana comb. et stat. nov., a species in the Drosera peltata (Droseraceae) complex. Muelleria 36: 97-106.

Fleischmann, A., Cross, A.T., Gibson, R., Gonella, P.M., and Dixon, K.W. 2018. Systematics and evolution of Droseraceae. In: Ellison, A.M., and Adamec, L. (eds.): Carnivorous plants: physiology, ecology, and evolution. Oxford University Press, 45-57.

Krueger, T., and Fleischmann, A. 2021. A new species of Drosera section Arachnopus (Droseraceae) from the western Kimberley, Australia, and amendments to the range and circumscription of Drosera finlaysoniana. Phytotaxa 501: 56-84.

Krueger, T.A., and Fleischmann, A. 2020. When three become two: Drosera coalara links Drosera citrina with Drosera nivea. Carnivorous Plant Newsletter 49: 6-16.

Lowrie, A. 2014. Carnivorous Plants of Australia Magnum Opus. Redfern Natural History, Dorset. 3 Volumes.

Mathieson, M.T., and Thompson, S.L. 2020. Drosera buubugujin M.T.Mathieson (Droseraceae, Drosera section Prolifera C.T.White), a spectacular new species of sundew from the Cape York Peninsula bioregion. Austrobaileya 10: 549-557.

Percy-Bower, J.M., and Parker, C.M. 2019. Updates to Western Australia's vascular plant census for 2018. Nuytsia 30: 1-18.

Queensland Department of Environment and Science 1995-2021. Threatened Species Listing report. https://www.qld.gov.au/environment/plants-animals/conservation/threatened-wildlife/ threatened-species [Accessed 19 Nov 2021]

Robinson, A.S., Cross, A.T., Meisterl, M.E., and Fleischmann, A. 2018. A new pygmy sundew, Drosera albonotata (Droseraceae), from the western Wheatbelt and an updated diagnostic key to the orange-flowered pygmy Drosera of Western Australia. Phytotaxa 346: 221-236.

Utz, Y.-A., and Gibson, R. 2017. Drosera huegelii Endl. var. phillmanniana from the Stirling Range, south western Australia. Carnivorous Plant Newsletter 46: 132-138.

Western Australian Herbarium 1998-. Florabase - the Western Australian Flora. Department of Biodiversity, Conservation and Attractions. https://florabase.dpaw.wa.gov.au/ [Accessed 19 Nov 2021] 